\title{
Dissolved Air Flotation for Fiber Removal from Clear Water
}

\author{
Bruna Luiza Manago ${ }^{1}$, Carlos Magno de Sousa Vidal ${ }^{2}$, Jeanette Beber de Souza², \\ Ludmila Carvalho Neves ${ }^{1}$, Kelly Geronazzo Martins ${ }^{2}$ \\ ${ }^{1}$ Department of Forest Science, Universidade Estadual do Centro Oeste - UNICENTRO, Irati/PR, Brazil \\ ${ }^{2}$ Department of Environmental Engineering, Universidade Estadual do Centro Oeste - UNICENTRO, Irati/PR, Brazil
}

\begin{abstract}
We investigated the use of dissolved air flotation (DAF) to treat clear water effluent from the paper industry in order to remove fibers. The dosage of polyaluminium chloride (PAC) was varied in the following concentrations: $0,75,100,125,150$ and $175 \mathrm{mg} / \mathrm{L}$; as well as bubble rise velocity of 18 and $9 \mathrm{~cm} / \mathrm{min}$ for two types of paper wastewater: print and gloss. Data were statistically analyzed through factorial arrangement $6 \times 2 \times 2$. The treatment of the print paper effluent showed better performance in removing the analyzed parameters with an optimal dosage of $100 \mathrm{mg} / \mathrm{L} \mathrm{PAC}$, whereas the gloss paper effluent treatment had satisfactory removal of analyzed parameters with an optimal dosage of $150 \mathrm{mg} / \mathrm{L}$ of PAC. This led to the observation that the high efficiency directly obtained with the DAF in conjunction with the use of PAC coagulant was an excellent primary treatment option for effluent resulting from the paper industry.
\end{abstract}

Keywords: fiber recovery, paper industry, total suspended solids. 


\section{INTRODUCTION}

Three forces are currently driving the wastewater treatment market: increasing industrialization, which requires stricter standards for the disposal of effluent to preserve the environmental characteristics of the site; increasing water costs, encouraging water-saving measures and, where possible, its reuse and recycling; and the production and recovery of increasingly advantageous value-added by-products (Pires et al., 2013).

In recent decades, the pulp and paper industry has tended to adapt its productive and operational processes with the main objective of reducing costs and waste, as well as improving its environmental performance. In the Kraft process, even factories with best production practices in terms of water use have a consumption varying from 40 to $55 \mathrm{~m}^{3} /$ tsa, resulting in considerable volumes of effluent for treatment (Brazilian Technical Association of Pulp and Paper, 2011).

In the paper machine, an effluent called white water is generated during the process of forming, pressing and drying the sheet, mainly consisting of a high concentration of cellulosic fibers, mineral filler, settling solids, suspended solids, starch, glue, and fine fibers which increases organic matter content, color and turbidity of the effluent (Sousa et al., 2011).

In the forming part of a sheet of paper in the production process, the white water is collected in channels, located just below the screen. After collection, white water passes through fiber recovery equipment, with both clear water and fibers being reusable in the system in different ways, depending on the quality of recovery of both (Lan et al., 2009).

In the papermaking process, pulp represents the largest percentage of mass and cost. Cellulose constitutes about $80 \%$ of the paper composition and contributes approximately $50 \%$ to the total cost. This makes the minimization of fiber losses from paper machines a desirable outcome (Belosinschi \& Bobu, 2007).

The recovery and reintroduction of cellulose fibers present in the white water from the production process has a number of advantages: it allows for substituting a great part of the treated water use, reduces unit costs, reduces solid waste generation, minimizes the need for landfill sites for final disposal, and reduces fiber overload at the industrial effluent treatment plant, which causes a number of operational problems at the station when present (Foelkel, 2007).

As a basic principle, fiber recovery seeks to prevent it being lost during the process. There are several fiber recovery techniques, such as filters, sieves, decanters, and clarifiers including dissolved air flotation (DAF), which present different recovery percentages (Foelkel, 2007).

DAF technology consists of a three-phase process in which solid particles (flakes) suspended in the liquid medium (water) are separated by the action of gas (air) microbubbles. These air microbubbles adhere to the surface of the flakes, increasing the intensity of the thrust acting on them, which causes them to rise to the surface of the floatation tank where the sludge accumulates over a period of time until collected by the appropriate mechanisms on the surface of the float (Reali, 1991).

DAF has been widely used in the petrochemical, mining, food processing, drinking water treatment and paper and pulp industries (Miranda et al., 2009). The most common application of DAF in the pulp and paper industry is mainly in primary treatment to clarify raw effluent, with an efficiency of up to $98 \%$ for suspended solids removal (Costanzi \& Daniel, 2002).

This study investigated the use of DAF to treat clear water effluent from the paper industry, aiming to remove fibers lost in the production process.

\section{MATERIAL AND METHODS}

The present study was developed in a medium-sized paper factory in the mid-west region of Parana, which produces a total of 115,000 tons per year of offset and kraft paper, with an estimated wastewater production of approximately $500 \mathrm{~m}^{3} /$ day and concentration of suspended solids in the effluent from 350 to $500 \mathrm{mg} / \mathrm{L}$.

It is a case study in which the company already had a disc filter for fiber recovery, but the efficiency was around $60 \%$ due to operational and technical problems, resulting in fiber losses and an increase in the generation of primary sludge at the end of the treatment system. 
The volume of white water generated in the process that was not reused passed through the disk filter for recovery of the fibers and clearing the water for reuse, resulting in an effluent called clear water. The clear water effluents characterized and analyzed in the present study come from two types of offset paper produced by the company: gloss and print.

Preliminary characterization of the clear water effluent and the analyzed parameters were: $\mathrm{pH}$, temperature, chemical oxygen demand (COD), turbidity, total suspended solids (TSS) and apparent color. All analyses were performed according to Standard Methods for the Examination of Water and Wastewater $21^{\text {st }}$ edition (APHA, 2005).

The effluent was heated to $37^{\circ} \mathrm{C}$ in order to obtain a temperature in the same operating conditions during the industrial process, and it was subsequently submitted to treatment, in triplicate, by means of coagulation/flocculation/flotation in laboratory bench equipment with batch operation according to the methodology proposed by Di Bernardo \& Centurione (2003). The coagulant dosage range of polyaluminium chloride (PAC) of 0 (without addition of coagulant) $75,100,125,150$ and $175 \mathrm{mg} / \mathrm{L}$ was tested, and rise velocity of the air bubbles of RV1 $(18 \mathrm{~cm} / \mathrm{min})$ and $\operatorname{RV} 2(9 \mathrm{~cm} / \mathrm{min})$ was also tested to verify which of the configurations would behave best in terms of treatment efficiency, to optimize the process.

In order to evaluate the fiber removal capacity and efficiency during treatments, concentrations of TSS, COD, apparent color and turbidity were determined.

PAC is a high molecular weight mineral polymer which, due to the characteristic of its molecular structure, has advantages in flocculation compared to other non-prepolymerized inorganic coagulants whose efficacy is on average 2.5 times higher than the others, as well as having advantages such as the use of a large $\mathrm{pH}$ range, the formation of large, rigid and heavy flakes, as well as the ability to remove organic and inorganic fillers (Zouboulis \& Tzoupanos, 2010).

The physicochemical characteristics of the PAC used are listed in Table 1.

The parameters set for the DAF assays were chosen from values of the area-specific literature (Pioltine \& Reali, 2011; Quartaroli et al., 2014) and are listed in Table 2 .
Table 1. Physicochemical characteristics of the PAC coagulant used.

\begin{tabular}{cc}
\hline Physical state & Liquid \\
\hline Solids concentration percentage & $36.86 \%$ \\
\hline Density at $25^{\circ} \mathrm{C}$ & $1.260 \mathrm{~g} / \mathrm{cm}^{3}$ \\
$\mathrm{pH}$ & 2.00 to 3.20 \\
\hline
\end{tabular}

Table 2. Settings of DAF tests.

\begin{tabular}{|cc|}
\hline Parameter & Configuration \\
\hline Velocity gradient for rapid mixing & $500 \mathrm{~s}^{-1}$ \\
\hline Detention time for rapid mixing & $60 \mathrm{~s}$ \\
\hline Velocity gradient for flocculation & $50 \mathrm{~s}^{-1}$ \\
\hline Residence time for flocculation & $5 \mathrm{~min}$ \\
\hline Recirculation & $20 \%$ \\
\hline Saturation pressure & $5 \mathrm{bar}$ \\
\hline Saturation time & $15 \mathrm{~min}$ \\
\hline
\end{tabular}

\section{STATISTICAL ANALYSIS}

The statistical analysis performed for the research consisted of a $6 \times 2 \times 2$ factorial arrangement with a completely randomized design. Six different dosages of PAC coagulant were tested, two different types of paper effluent and two rise velocities of the air bubbles tested. The response variables chosen were: apparent color, turbidity, COD and TSS.

The statistical analyses and graphs generated were obtained using Statistica ${ }^{\circledR}$ software version 7.0. Data were transformed (log) to adhere to gaussianity of residue, verified by the Shapiro-wilk test, and homogeneity of variance verified by Bartlett's test at 5\% significance. After analysis of variance, multiple mean comparison tests were performed for each parameter using the Tukey test with a significance level of $5 \%$.

\section{RESULTS AND DISCUSSION}

\subsection{Characterization of the effluent clear water}

In Table 3, the data with the physicochemical characterization of the clear water effluents for the types of print and gloss paper are presented.

Characterization of the clear water effluent (Table 3) showed a high concentration of fibers in the evaluated industry effluent, which could be removed. This effluent containing high fiber and organic matter loads went 
directly to the company's wastewater treatment plant, generating fiber waste and making it difficult to treat the final effluent, justifying the need to introduce a more efficient primary treatment system.

By specifically analyzing the parameter related to the fibers (total suspended solids), even after the effluent had gone through the process of recovering fibers from the paper machine, the values were still high: $545 \mathrm{mg} / \mathrm{L}$ and $410 \mathrm{mg} / \mathrm{L}$ (Table 3) for effluents from the production of print and gloss paper, respectively. Fiber removal in the disk filter system in the paper machine was around 60\%; this is not satisfactory, since Foelkel (2007) establishes that a simple filter can recover between 85 and $95 \%$ of the fibers.

For common filters, usual characteristics for clear waters are low suspended solids (50 to $80 \mathrm{mg} / \mathrm{L}$ ), and

Table 3. Physicochemical characterization from print and gloss paper clear water.

\begin{tabular}{|ccc|}
\hline Parameter & Print & Gloss \\
\hline Color $($ Pt-Co units $)$ & 1,104 & 1,760 \\
\hline Turbidity $(\mathrm{NTU})$ & 812 & 544 \\
\hline COD $(\mathrm{mg} / \mathrm{L})$ & 446 & 570 \\
\hline TSS $(\mathrm{mg} / \mathrm{L})$ & 545 & 410 \\
\hline Temperature $\left({ }^{\circ} \mathrm{C}\right)$ & 37 & 37 \\
\hline $\mathrm{pH}$ & 7.8 & 7.8 \\
\hline
\end{tabular}

these suspended solids consist of fibers, mineral fillers, etc. The COD levels of these clarified waters are low, ranging from 40 to $100 \mathrm{mg} / \mathrm{L}$, due to the presence of small or diluted organic compounds (fibrils, fine fibers, starch, etc.). It can be observed that the COD concentration of the studied effluent is up to $81 \%$ above the usual values found in the literature for waters that have already undergone a fiber recovery process. Another characteristic of the effluent is the high temperatures, which vary from 30 to $40^{\circ} \mathrm{C}$ due to the production process and the use of steam in paper drying (Foelkel, 2007).

\subsection{Efficiency of removing the studied parameters}

Tables 4 and 5 show the efficiency for removing the main response variables studied, calculated on the basis of the values of the two raw clear waters in relation to the residuals after DAF treatment.

In analyzing Tables 4 and 5, it is possible to observe that the rise velocities 1 and 2 presented similar performances in removing the studied parameters. In general, satisfactory removal efficiency was obtained for the print paper effluent (Table 4): apparent color 96.7\%, turbidity $99.5 \%$ and TSS 98.6\%. High efficiency

Table 4. Removal efficiency of DAF for apparent color, turbidity, chemical oxygen demand (COD) and total suspended solids (TSS) parameters in the treatment of print paper clear water.

\begin{tabular}{|c|c|c|c|c|c|c|c|c|}
\hline Print & \multicolumn{2}{|c|}{ Apparent color (\%) } & \multicolumn{2}{|c|}{ Turbidity (\%) } & \multicolumn{2}{|c|}{ COD $(\%)$} & \multicolumn{2}{|c|}{ TSS (\%) } \\
\hline CD (mg/L) & RV1 & RV2 & RV1 & RV2 & RV1 & RV2 & RV1 & RV2 \\
\hline 0 & 94.1 & 94.7 & 91.9 & 92 & 35 & 33.9 & 96.7 & 97.5 \\
\hline 75 & 75.5 & 89.3 & 98.8 & 99.1 & 11.7 & 11.1 & 95 & 96.2 \\
\hline 100 & 92.6 & 93.9 & 99.3 & 99.4 & 17.8 & 10.9 & 98.2 & 98.2 \\
\hline 125 & 94.9 & 94.8 & 99.5 & 99.5 & 23.3 & 21.9 & 98.3 & 98.6 \\
\hline 150 & 92 & 93.7 & 98.9 & 99.4 & 12.6 & 12 & 96.7 & 97.3 \\
\hline 175 & 95.4 & 96.7 & 99.4 & 99.5 & 21.1 & 24.1 & 93.6 & 96.8 \\
\hline
\end{tabular}

Where: $\mathrm{CD}=$ Coagulant Dosage; RV1 $=18 \mathrm{~cm} / \mathrm{min} ; \mathrm{RV} 2=9 \mathrm{~cm} / \mathrm{min}$.

Table 5. Removal efficiency of DAF for apparent color, turbidity, chemical oxygen demand (COD) and total suspended solids (TSS) parameters in the treatment of gloss paper clear water.

\begin{tabular}{|c|c|c|c|c|c|c|c|c|}
\hline Gloss & \multicolumn{2}{|c|}{ Apparent color (\%) } & \multicolumn{2}{|c|}{ Turbidity (\%) } & \multicolumn{2}{|c|}{ COD (\%) } & \multicolumn{2}{|c|}{ TSS (\%) } \\
\hline $\mathrm{CD}(\mathrm{mg} / \mathrm{L})$ & RV1 & RV2 & RV1 & RV2 & RV1 & RV2 & RV1 & RV2 \\
\hline 0 & 90.5 & 90.6 & 87.9 & 90.3 & 70.1 & 70.9 & 93.2 & 94.1 \\
\hline 75 & 90.1 & 93.4 & 93.4 & 96.8 & 50.8 & 64 & 81.4 & 88.4 \\
\hline 100 & 90.6 & 93.1 & 91.4 & 94.9 & 43.3 & 46.2 & 85 & 88.3 \\
\hline 125 & 94.4 & 93.4 & 85.7 & 94.4 & 92.5 & 89.8 & 86.3 & 90.7 \\
\hline 150 & 91.2 & 91.4 & 92.5 & 95.5 & 92.5 & 92.6 & 90.9 & 90.7 \\
\hline 175 & 92.6 & 94 & 98 & 98.2 & 82.4 & 88.1 & 87.5 & 89.4 \\
\hline
\end{tabular}

Where: $\mathrm{CD}=$ Coagulant Dosage; RV1 $=18 \mathrm{~cm} / \mathrm{min} ; \mathrm{RV} 2=9 \mathrm{~cm} / \mathrm{min}$. 
was also observed with DAF for paper gloss effluent, with removal of apparent color of $94.4 \%$, turbidity 98.2\% and TSS 94\% (Table 5).

This result can be explained due to the composition of each paper type; print (Table 3) has higher fiber content and loads in the inlet production and throughout the system. Theoretically more fibers/fillers are lost during the paper-forming process in print paper, which in turn facilitates the formation of denser flakes, which favor flotation (Di Bernardo et al., 2011).

The concentration of fibers in the inlet in the gloss paper production process is 0.5 to $0.7 \%$ and 0.7 to $1.4 \%$ in the print. This was confirmed by characterizing the effluent (Table 3) from the TSS concentration, which is directly correlated with the presence of fibers in the effluent (Foelkel, 2007).

Regarding the removal of the COD parameter, which corresponds to the organic matter content dissolved in the effluent, the best performance was observed for the gloss paper effluent (Table 5) whose COD removal was $92.6 \%$ compared to the highest COD removal percentage (35\%) for the effluent of print paper (Table 4).

The color of a water sample is directly associated with the degree of light reduction intensity that it undergoes due to the presence of dissolved solids, mainly organic and inorganic colloidal material (Di Bernardo et al., 2011). In this case, both the origin of the color and the high COD concentration may arise from effluents from paper and cellulose industries, and contain lignin, cellulose, starch, calcium carbonate, etc. (Sousa et al., 2011).

\subsection{Apparent color}

The variation in apparent color can be seen in Figure 1.

In Figure 1 it is indicated that the print paper effluent presented the highest index of apparent color removal. We can affirm that there was no statistical difference between the rise velocities tested for the print paper effluent.

In the gloss paper effluent, the rise velocity 2 was better at removing the apparent color at the dosage of 100 and $75 \mathrm{mg} / \mathrm{L}$. There was no statistical difference between the two velocities in the other dosages.

The maximum removal value was $96.7 \%$ for print paper effluent (Table 4) at a dose of $175 \mathrm{mg} / \mathrm{L}$ (Figure 1), which was statistically similar to the other dosages.

For gloss paper effluent, all dosages allowed more than $90 \%$ color removal, with $125 \mathrm{mg} / \mathrm{L}$ being the best dosage, and with a maximum removal efficiency
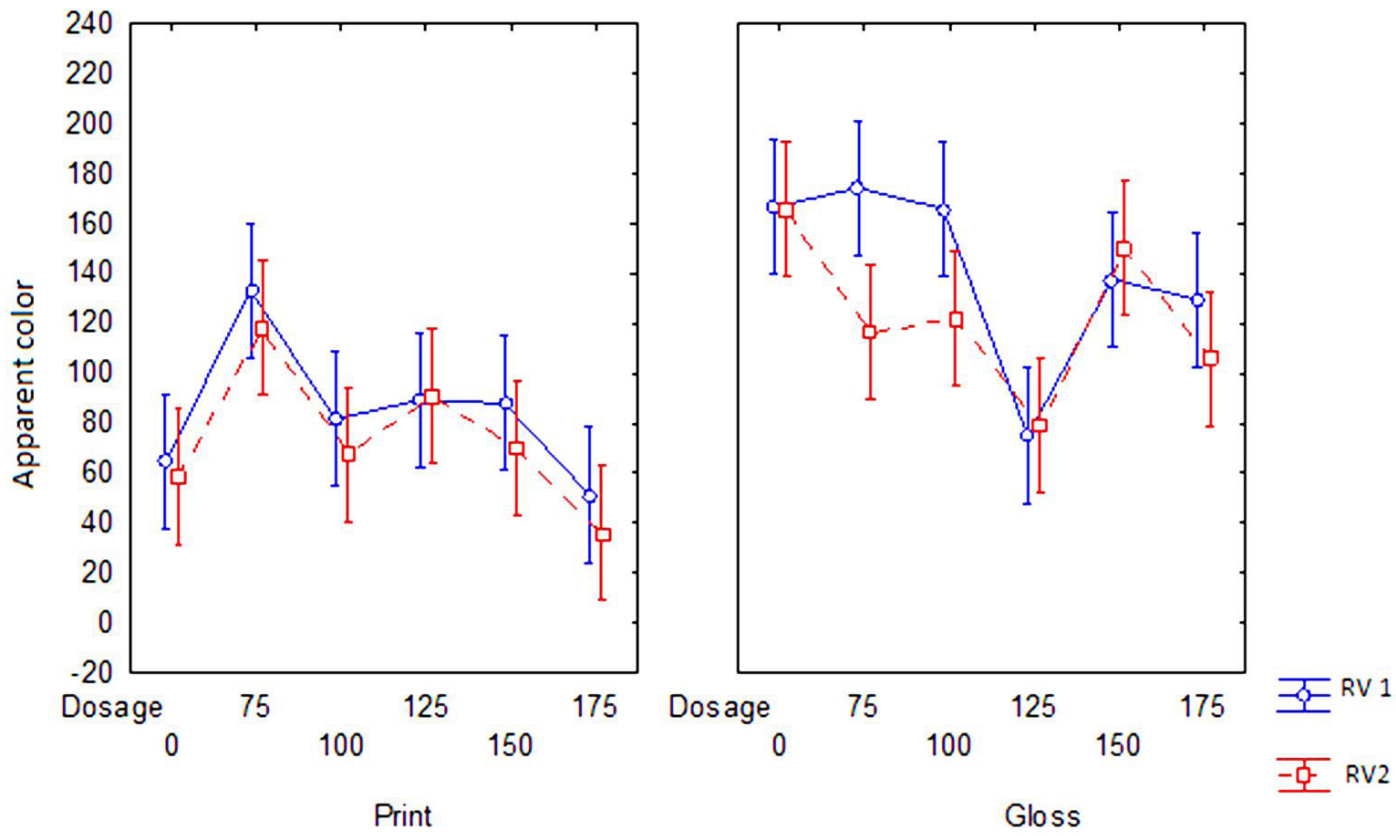

Figure 1. Interaction between: dosage x rise velocity x paper type for apparent color. 
of $94.4 \%$ (Table 5) without statistically differing from the $175 \mathrm{mg} / \mathrm{L}$ (Figure 1). It is important to note that the apparent color of the gloss paper effluent is higher than that of the print, surpassing it by $656 \mathrm{Pt}-\mathrm{Co}$ units, and yet it still satisfactorily removed the parameter.

Clarification by means of flotation can be adopted when the raw water has a relatively high color in relation to the turbidity since it facilitates the removal of light flakes, usually produced after coagulation and flocculation (Di Bernardo et al., 2011). This can be observed in Table 3 in which the apparent color of the print and gloss paper effluents were respectively 1,104 and 1,760 Pt-Co units, compared to the turbidity of 812 NTU for print and 544 NTU for gloss.

\subsection{Turbidity}

The variation in turbidity can be seen in Figure 2.

Figure 2 shows that there was no statistical difference between rise velocities 1 and 2 for print paper effluent. For the gloss paper effluent, velocity $2(9 \mathrm{~cm} / \mathrm{min})$ was statistically the best performance for turbidity removal at dosages $0,75,100$ and $150 \mathrm{mg} / \mathrm{L}$.

In the interaction between the three studied factors (Figure 2), it is possible to conclude that turbidity presented the highest removal efficiencies for the print paper effluent at the $125 \mathrm{mg} / \mathrm{L}$ dosage with $99.5 \%$ removal (Table 4), being statistically equal to the other three dosages (100, 150 and $175 \mathrm{mg} / \mathrm{L}$ ).

For the gloss paper effluent, a maximum of $98 \%$ turbidity removal (Table 5) was obtained for the $175 \mathrm{mg} / \mathrm{L}$ dosage during the interaction of paper type, dosage and rise velocity factors (Figure 2).

Lima \& Reali (1997) obtained similar results with paper-based effluents using DAF as treatment, varying the dosage of PAC (0 to 400) and the $\mathrm{pH}$ of the sample (5.5 to 8.0). The highest removal efficiencies were obtained for $\mathrm{pH} 8$ at the dosage of $200 \mathrm{mg} / \mathrm{L}$, with remaining turbidity values of 43 and $32 \mathrm{NTU}$ at the rise velocities of 22 and $8.89 \mathrm{~cm} / \mathrm{min}$, respectively.

\subsection{Chemical Oxygen Demand (COD)}

The variation in COD can be seen in Figure 3.

Figure 3 shows that there was no statistical difference between the rise velocities for the print paper effluent, independent of the interactions between the paper type and the dosages. For gloss paper effluent, rise velocities are statistically similar for all dosages except for the $75 \mathrm{mg} / \mathrm{L}$ dosage, in which velocity $2(9 \mathrm{~cm} / \mathrm{min})$ represented a better performance to remove the COD parameter.
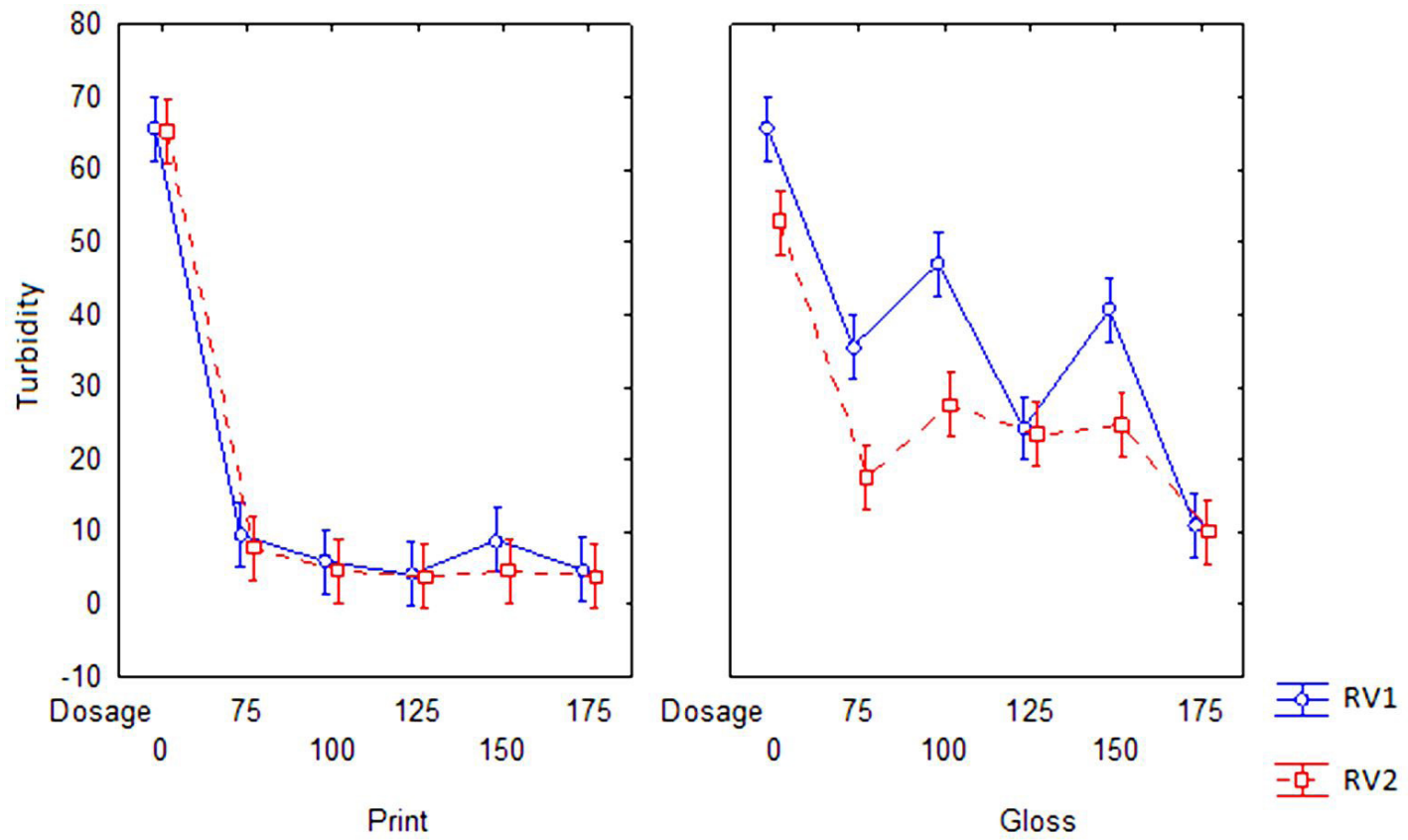

Figure 2. Interaction between: dosage $\mathrm{x}$ rise velocity $\mathrm{x}$ paper type for turbidity. 

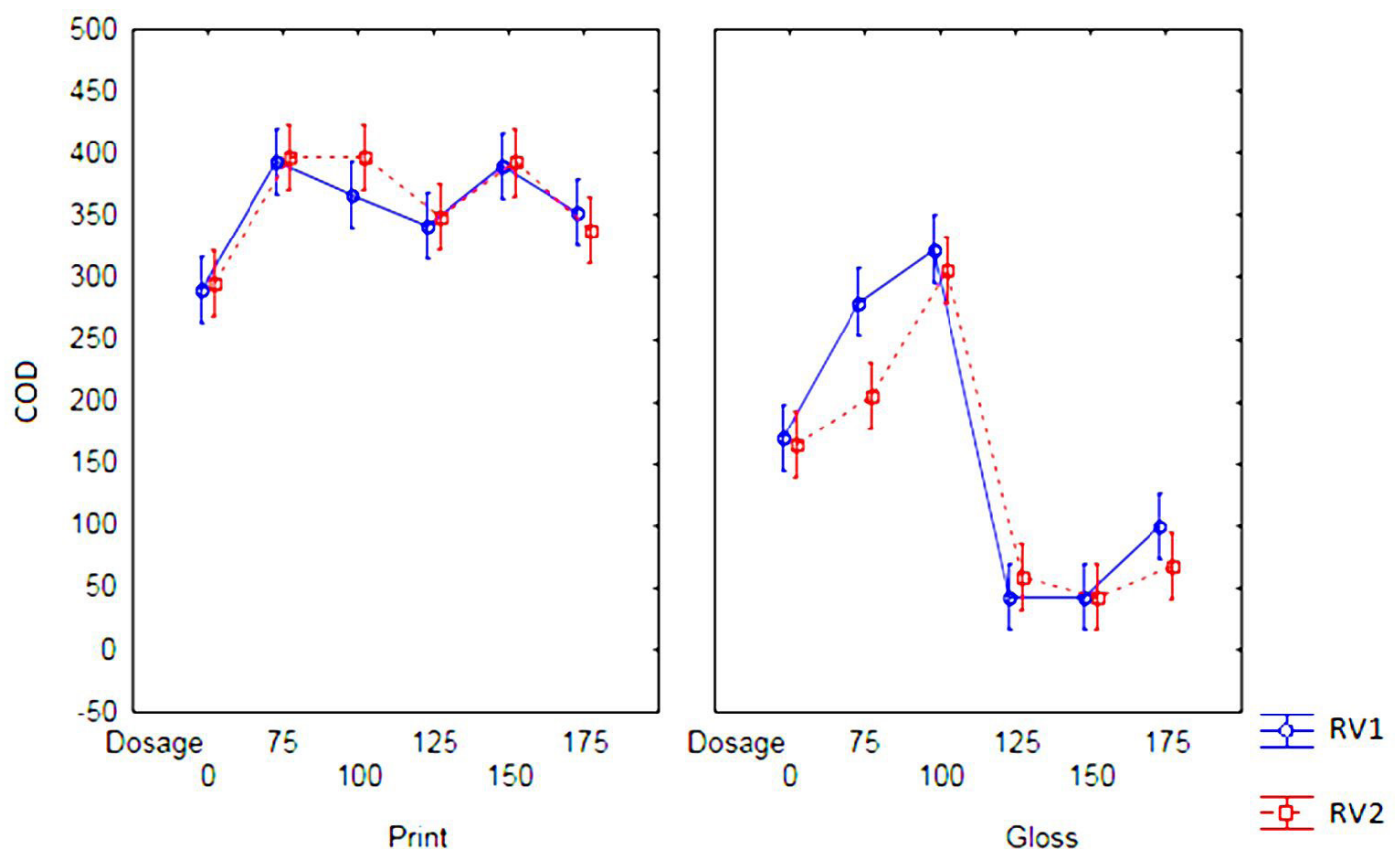

Figure 3. Interaction between: dosage x rise velocity x paper type for COD.

For the print paper effluent, the best dosages statistically were 0,125 and $175 \mathrm{mg} / \mathrm{L}$. For the gloss paper effluent, the dosages 125,150 and $175 \mathrm{mg} / \mathrm{L}$, which are statistically similar, are highlighted (Figure 3).

Based on Figure 3, we can see that the gloss paper effluent had the highest COD reduction, with maximum removal efficiency of $92.6 \%$ for the $150 \mathrm{mg} / \mathrm{L}$ dosage (Table 5). The best removal (35\%) was obtained for the print paper effluent without coagulant addition (Tables 4).

Kaya \& Kurama (1999) state that treatment by DAF equipment should generally have COD removal efficiency between $80-89 \%$. However, Kuhn et al. (1996) reported removal of COD from 30 to $40 \%$ using DAF technology, proving that the percentage of removal can vary according to the composition of each treated effluent.

In the case of the print paper clear water, where the removal efficiencies of the COD parameter were statistically the same for the dosages of 125 and $175 \mathrm{mg} / \mathrm{L}$, and in the absence of coagulant addition, this could possibly be attributed to the remaining COD being in the form of organic matter dissolved in the effluent. Physical and chemical processes such as DAF remove lignin, high molecular weight chlorinated hydrocarbons, color, toxic substances and suspended solids. Compounds of soluble organic matter and low molecular weight such as dissolved solids however, are not efficiently removed (Sharma et al., 2014).

\subsection{Total suspended solids (TSS)}

TSS variation can be seen in Figure 4 .

Based on Figure 4, we can see that the rise velocities tested did not statistically differ for all the analyzed factors, except for the $75 \mathrm{mg} / \mathrm{L}$ dosage in the gloss paper effluent, where velocity 2 represented the best results in TSS removal.

In the print paper effluent treatment, the best overall fiber removal (TSS) was obtained (Figure 4) with a maximum value of $98 \%$ for the dosages of 100 and $125 \mathrm{mg} / \mathrm{L}$. The removal efficiency for all other dosages tested was above 93\% (Table 4). All can be considered statistically similar, demonstrating that this is a highly effective treatment for the removal of the TSS parameter.

DAF technology is very useful when light flakes are to be floated, as this is a process for removing suspended insoluble materials present in waste water (Costanzi \& Daniel, 2002), such as the short fibers present in the print paper effluent. 


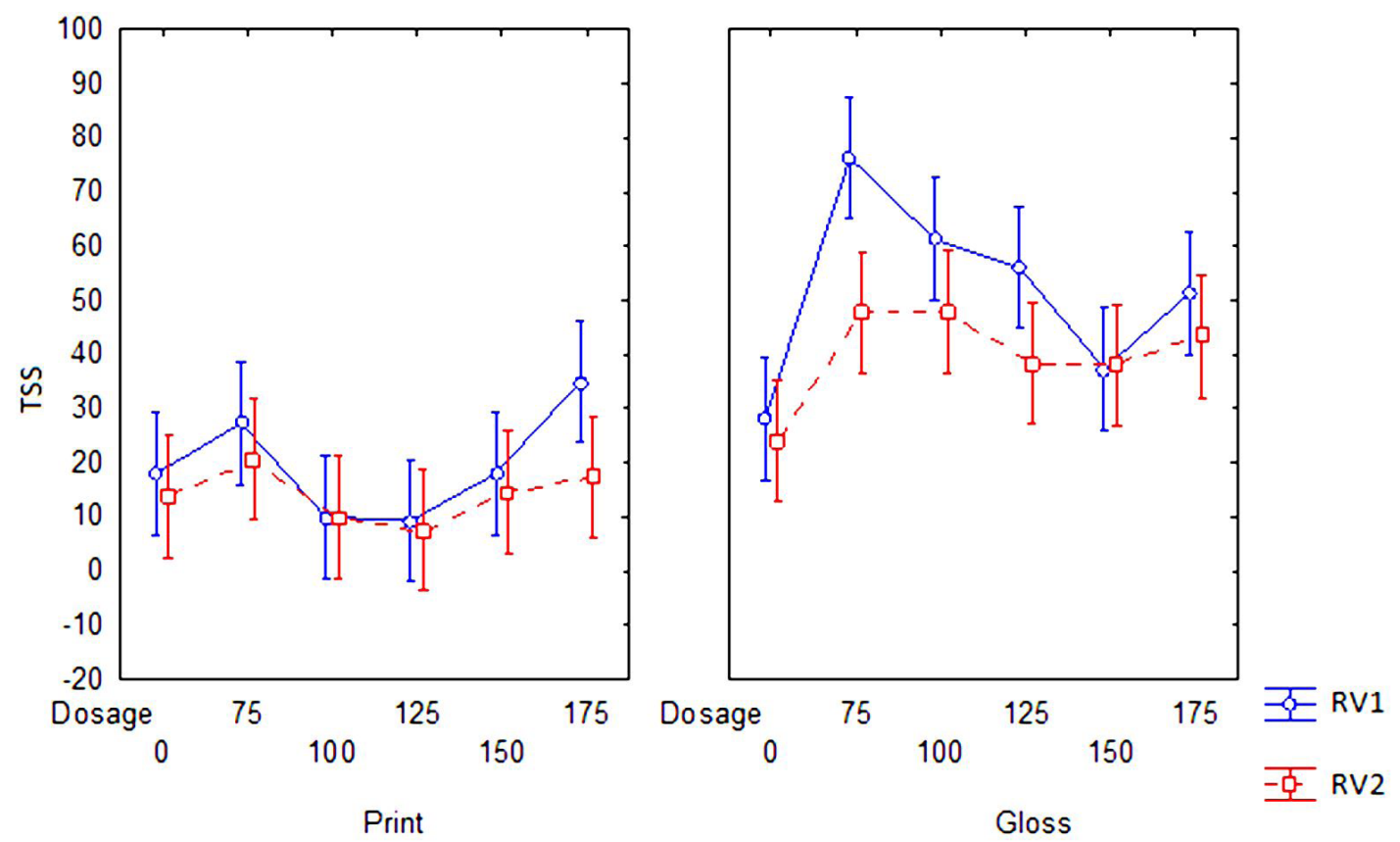

Figure 4. Interaction between: dosage $\mathrm{x}$ rise velocity $\mathrm{x}$ paper type for TSS.

For the gloss paper effluent treatment, good TSS removal results were also obtained with $94 \%$ without the addition of coagulant, being statistically similar to the dosages 125,150 and $175 \mathrm{mg} / \mathrm{L}$ with $90.9 \%$ maximum removal. The lowest value obtained for TSS removal was for the dosage of $75 \mathrm{mg} / \mathrm{L}$, with $81.4 \%$. These values are accepted within the range of $70-98 \%$, as described by Ben et al. (2004) as typical for the removal of suspended solids using DAF as the primary treatment. The use of coagulants is generally recommended to achieve greater removal efficiency.

Lima \& Reali (1997) obtained good results using DAF in paper machine effluent without the aid of coagulant, attributing this behavior to the use of starch, cationic polymer and other additives used as retention aids that contribute to the formation of the paper sheet in the machine.

\subsection{Optimal configuration}

Taking into account the flow rate, rise velocity 1 $(18 \mathrm{~cm} / \mathrm{min})$ is the most indicated because it showed good removal performance of the parameters, and in most cases it was statistically similar to velocity 2 . Thus, the volume of effluent treated per amount of time will be higher, which implies an industrial scale in a more compact unit, maintaining the same removal efficiency.

The optimal dosage was chosen hierarchically based on the statistics and the best removal efficiencies of TSS, COD, turbidity and apparent color parameters. In opting for the best treatment efficiencies and the lower applied dosages, the dosages of 100 and $150 \mathrm{mg} / \mathrm{L}$ were chosen for the print and gloss paper effluents, respectively.

With the possibility of a compact flotation tank, low operating costs and good energy efficiency, DAF proved to be especially suitable for primary treatment applications in pulp and paper effluents due to its high hydraulic capacity and advanced performance, and when specifically applied to recover suspended solids which contain fibers, fines, and fillers.

\section{CONCLUSIONS}

The results indicate that the addition of a primary treatment by DAF with the aid of the PAC coagulant improves the characteristics of the clear water effluent, facilitating flotation of the suspended material.

The total suspended solids, which represent the fibers contained in the clear water effluent, presented 
excellent removal efficiency in relation to the PAC coagulant dosage used in DAF treatment, reaching $98 \%$ of TSS removal and with a minimum of $81.7 \%$.

The optimal configuration of the DAF treatment of the gloss paper effluent presented an efficiency of more than $90 \%$ for all analyzed parameters, with the dosage of $150 \mathrm{mg} / \mathrm{L}$ of PAC and a rise velocity of $18 \mathrm{~cm} / \mathrm{min}$.

The optimal configuration of the DAF treatment of the print paper effluent reached removal efficiency values above $92 \%$ for all parameters, except for COD (17.8\%), for the dosage of $100 \mathrm{mg} / \mathrm{L}$ of PAC and rise velocity of $18 \mathrm{~cm} / \mathrm{min}$.

\section{SUBMISSION STATUS}

Received: 7 apr. 2016

Accepted: 2 june 2017

\section{CORRESPONDENCE TO}

\section{Bruna Luiza Managó}

Department of Forest Science, Universidade

Estadual do Centro-Oeste - UNICENTRO,

Rod. PR 153, Km 7, Bairro Riozinho,

CP 21, CEP 84500-000, Irati, PR, Brazil

e-mail: blmanago@gmail.com

\section{FINANCIAL SUPPORT}

Coordenação de Aperfeiçoamento de Pessoal de Nível Superior (CAPES).

\section{REFERENCES}

American Public Health Association - APHA. Standard Methods for Examinations of Water and Wastewater. 21st ed. Washington: APHA; AWWA; WEF; 2005.

Belosinschi D, Bobu E. Process water of papermaking: model building and characterization. Environmental Engineering and Management Journal 2007; 6(4): 261-268.

Ben Y, Dorris GM, Pagé N. Characterization of dissolved air flotation rejects. Pulp \& Paper 2004; 105(11): 246-251.

Brazilian Technical Association of Pulp and Paper. Benchmarking de Segurança do Trabalho na Cadeia Produtiva do Papel: Dados de 2010. Curitiba: ABCTP; 2011.

Costanzi RN, Daniel LA. Estudo do tratamento de efluentes de uma fábrica de papel para imprimir visando o reuso por flotação e sedimentação. Engenharia Sanitária e Ambiental 2002; 7(3-4): 156-160

Di Bernardo L, Centurione PL Fo. Procedimento para execução de ensaios de flotação/filtração em equipamento de bancada. Engenharia Sanitária e Ambiental 2003; 8(1-2): 39-44.

Di Bernardo L, Dantas ADB, Voltan PEN. Tratabilidade de água e resíduos gerados em estações de tratamento de água. São Carlos: Ldibe; 2011.

Foelkel C. Ecoeficiência na gestão da perda de fibras de celulose e do refugo gerado na fabricação de papel. Porto Alegre: Eucalytpus Online Books \& Newsletter; 2007.

Kaya M, Kurama $\mathrm{H}$. The role of flotation in waste recycling/recovery. In: Proceedings of the VIII Balkan Mineral Processing; 1999; Belgrade. Yugoslavia: Björkman; 1999. p. 729-736.

Kuhn D, Puhar EM, Mahony L. The impact of water clarification on deinking systems. In: Recycling Symposium; 1996; New Orleans, United States. Peachtree Corners: TAPPI; 1996. p. 333-337.

Lan X, Liu Y, Lv H, Wang X, Leng J, Du S. Fiber reinforced shape-memory polymer composite and its application in a deployable hinge. Smart Materials and Structures 2009; 18(2): 1-6. http://dx.doi.org/10.1088/0964-1726/18/2/024002.

Lima MRA, Reali MAP. Tratamento físico-químico das água residuárias de uma indústria de papel utilizando-se a flotação por ar dissolvido. In: Anais do XIX Congresso Brasileiro de Engenharia Sanitária e Ambiental; 1997; Foz do Iguaçu. São Paulo: ABES; 1997. p. 49-61.

Miranda R, Negro C, Blanco A. Internal treatment of process waters in paper production by dissolved air flotation with newly developed chemicals. 2. Field trials. Industrial \& Engineering Chemistry Research 2009; 48(7): 3672-3677. http://dx.doi.org/10.1021/ie801826m.

Pioltine A, Reali MAP. Emprego de bomba multifásica como unidade geradora de microbolhas de ar em sistema de flotação aplicado ao pré-tratamento de efluente têxtil. Engenharia Sanitária e Ambiental 2011; 16(2): 167-174. http://dx.doi.org/10.1590/S1413-41522011000200010.

Pires EC, Damianovic MHRZ, Nery VD. Tratamento de águas residuárias industriais. In: Calijuri MC, Cunha DGF. Engenharia ambiental: conceitos, tecnologia e gestão. Rio de Janeiro: Elsevier; 2013.

Quartaroli L, Kuritza JC, Cavallini GS, Vidal CMS, Souza JB. Aplicação de polímeros aniônico e catiônico na flotação por ar dissolvido como forma de pós-tratamento de efluente de indústria de papel e celulose. Scientia Forestalis 2014; 2(101): 57-67.

Reali MAP. Concepção e avaliação de um sistema compacto para tratamento de água utilizando o processo de flotação por ar dissolvido e filtração com taxa declinante [tese]. 
São Carlos: Departamento de Hidráulica e Saneamento, Universidade de São Paulo; 1991.

Sharma R, Chandra S, Singh A, Singh K. Degradation of pulp and paper mill effluents. The IIOAB Journal 2014; 5(3): 6-12.

Sousa AJCL, Reis C, Reis EL, Silva CM, Almeida A, Moreira GC et al. Remoção de cálcio de efluente de máquina de papel por precipitação/coprecipitação. Tecnologica. 2011; 15(2): 62-66.

Zouboulis A, Tzoupanos N. Alternative cost-effective preparation method of polyaluminium chloride (PAC) coagulant agent: characterization and comparative application for water/wastewater treatment. Desalination 2010; 250(1): 339-344. http://dx.doi.org/10.1016/j. desal.2009.09.053. 